\title{
COMIC STRIPS FOR LANGUAGE TEACHING: THE BENEFITS AND CHALLENGES ACCORDING TO RECENT RESEARCH
}

\author{
Eka Anastasia Wijaya \\ English Language Education, Post-Graduate Program, Universitas Pendidikan Ganesha \\ ekaanastasia28@gmail.com \\ Ni Komang Arie Suwastini \\ English Language Education, Post-Graduate Program, Universitas Pendidikan Ganesha \\ arie.suwastini@undiksha.ac.id \\ Ni Luh Putu Sri Adnyani \\ English Language Education, Post-Graduate Program, Universitas Pendidikan Ganesha \\ sri.adnyani@undiksha.ac.id \\ Kadek Eva Krishna Adnyani \\ Japanese Language Education, Faculty of Language and Arts, Universitas Pendidikan Ganesa \\ krishna.adnyani@undiksha.ac.id
}

\begin{abstract}
Recent studies have argued for the use of comic strips in language teaching, while concerns with the challenges in its application are also frequently highlighted. Using George's (2008) model of literature review, the present study will elaborate on the use of comic strips as a medium of learning, its benefits, and the challenges in its implementation. The data sources are research articles related to the implementation of comic strips for language teaching, published in reputable international journals and accredited national journals from 2011 to 2020. The review reveals that previous studies have proven that comic strips in language teaching can promote students' vocabulary, improve students' grammar competence, support the students' reading skills, and help the students who lack writing skills. However, these studies also show concerns on challenges in implementing comic strips in language teaching, such as its relevance, the choices of the topics, and how it cannot support spoken skills as much as it would support the written skills. It implies that while comic strips can be good media for teaching language, teachers should also find strategies in overcoming the challenges that may occur during its implementation.
\end{abstract}

Keywords: comic strips, language teaching, teaching media, benefits, challenges

\section{A. INTRODUCTION}

ccording to Gilakjani, Ismail, \& Ahmadi (2011), each learner has their learning
modality such as visual, aural, read or write, kinaesthetic, or even the combination
of all this modality; hence it is called multimodal learning. A good teaching and learning process would consider the students' preferred modality (Ersani, Suwastini, Padmadewi, \& Artini, 2021; Suwastini, Rinawati, Jayantini, \& Dantes, 2021). One of the commonly used learning modalities is the visual modality. It is closely related to the audiovisual trend that affects a lot of students to enjoy visual audio and visual stimuli better than textual ones (Ariantini, Suwastini, Adnyani, Dantes, \& Jayantini, 2021; Hutapea \& Suwastini, 
2019; Listiani, Suwastini, Dantes, Adnyani, \& Jayantini, 2021; Puspawati, Suwastini, Hutapea, Dantes, \& Adnyani, 2021; Suwastini, Dantes, Jayanta, \& Suprihatin, 2020; Suwastini, Lasmawan, Artini, \& Mahayanti, 2020; Suwastini, Utami, \& Artini, 2020; Utami, Suwastini, Dantes, Suprihatin, \& Adnyani, 2021).

Comic strips are examples of multimodal texts that combine words and pictures for representing a story (Budiman, Sada, \& Wardah, 2018; Poai, 2018; Rengur \& Sugirin, 2019; Sarma, 2016). The combination provides a better visual modality that increases the students' motivation, improves the students' creative abilities, and promotes the creative learning process (Chirkova, Chernovets, \& Zorina, 2019; Gilakjani et al., 2011). According to Sarma (2016) and Symeon, as cited in Yunus, Salehi, Tarmizi, Idrus, \& Balaraman (2011), the use of comic strips in printed form for educational purposes began in the middle of the $20^{\text {th }}$ century in the USA and have become a trend because they are considered as effective media.

Comic strips are also beneficial in language teaching and learning. It could stimulate the students' competence in language learning and increase the students' attention and positive attitudes in the learning process (K1lıckaya \& Krajka, 2012; Sharma, 2020; Syafii, 2019). In addition, Cimermanová (2015) and Da Silva, Santos, \& Bispo (2017) stated that comic strips are helpful in language learning, especially vocabulary and expressions, grammar, and compositions. It could also be used to develop the students' visual literacy. Besides that, comic strips could increase the students' understanding of language usage because it enables them to pursue the language at ease (Sarma, 2016; Sharma, 2020). Therefore, it could be said that comic strips are beneficial for improving students' English learning as effective media in language teaching. Thus, comic strips are considered suitable for the current education system (Chaikovska, 2018).

Comic strips have been advocated to be suitable for language teaching and learning. Da Silva et al. (2017), Sarma (2016), and Syafii (2019) stated that the use of pictures as in comic strips could give an exciting atmosphere that can be seen in how it helps the students to express their emotion in the learning process. Therefore, the use of comics will make the students learn English in more enjoyable and interesting ways. Comic strips also help students generate their ideas and become a medium to develop and practice their target language (Megawati \& Anugerahwati, 2012; Syafii, 2019). Moreover, it could be used to teach vocabulary, grammar, reading skills, and writing skills, such as introducing modals and pronouns and changing direct speech into indirect speech in the speech balloon (Da Silva et al., 2017). Kohnke (2018) and Poai (2018) maintain that the advantages of using comic strips are permanent and comic strips could be read anywhere and everywhere. 
In line with the explanation about the benefits and the implementation of comic strips in language teaching and learning, the present study aims at critically reviewing experts' opinions and previous studies on the use of comic strips for language teaching. The review is expected to provide a comprehensive summary of the benefits of comic strips for language learners and provide a critical overview of the challenges in the implementation of comic strips in language classrooms. As a critical summary, this study can become a source that provides comprehensive information related to the implementation of comic strips in language teaching, providing a reliable source for teachers and educators in language teaching. This study also acts as a preliminary study for further research in the use of comic strips in language learning since experts have argued that the use of comic strips in language learning should be explored further (K1liçkaya \& Krajka, 2012; Sarma, 2016).

\section{B. REVIEW OF LITERATURE}

\section{Definition and Elements of Comic Strips}

Comic is a medium to express ideas in images combined with text or visual information (Sarma, 2016). Experts argue that the two most common forms of comics are comic strips and comic books (Poai, 2018; Rengur \& Sugirin, 2019; Suwastomo, 2016). Comic books are novels or collections of stories expressed in images, texts, and other visual information (Rengur \& Sugirin, 2019; Sarma, 2016; Suwastomo, 2016). Comic strips have similar components when compared to comic books; only they are shorter. When comic books can come in several books for conveying a story or a collection of short stories, a comic strip conveys a single story in a series of well-arranged pictures and textboxes ( $\mathrm{Al}$ Faruq \& Nurhalimah, 2019; Hamidah, USman, \& Muhsin, 2015; Humola \& Talib, 2016; Rengur \& Sugirin, 2019). A comic strip usually takes only three to eight panels to convey the whole story (Budiman et al., 2018; Poai, 2018).

According to Poai (2018), aside from the pictures, the elements of strips include panel, lettering, balloon, caption, and borders. The panel is the most basic element in comic strips. A panel can be square, round, or triangular. The panel is the place where all the other elements are conveyed. The pictures display the characters' appearance, actions, and facial expressions, while the lettering is any text on comic strips page used to emphasize important words. Balloons are for the texts, usually include a pointing edge that connects the balloons to the characters speaking or thinking of the words written in the texts. Speech balloons are usually on straight-edged balloons, while the thought balloons are usually bubble-edged. Captions are 
used for narration or transitional text. Borders are lines that enclose panels, balloons, and captions. Together, they convey a story in several well-sequenced panels.

\section{Procedures of Using Comic Strips as Teaching Media}

Experiments have been conducted to bring comic strips into language classrooms (see, for example, Cabrera et al., 2018, Chirkova et al., 2019; Da Silva et al., 2017; Hamidah et al., 2015; Kılıçkaya \& Krajka, 2012; Kohnke, 2018; Mahir, Ali, \& Amin, 2016; Megawati \& Anugerahwati, 2012; Merc, 2013; Rokhayani \& Utari, 2014; Sharma, 2020). One of the main reasons for using comic strips in language classrooms is that they are easy to read and make. Comic strips are traditionally made manually, with the artist drawing the panels for a story that he/she creates or those that are created by a writer. It is common for a comic strip to have joint authorship or single authorship with a credited illustrator or several credited illustrators. With technology development, comic strips can also be made digitally using applications like Pixton, Comic Life, Make Belief Comix, Strip Generator, Comic Creator, and Toondo (Cabrera et al., 2018; Da Silva et al., 2017; K1liçkaya \& Krajka, 2012). Teachers who want to use comic strips in their class can either make it manually or digitally. For example, https://www.smilebox.com/maker/comic-maker/ provides templates for comic strips that allow teachers to insert photographs into the panels to make comic strips. Website https://www.commonsense.org/education/top-picks/classroom-friendly-websites-and-appsfor-making-comics provides updated classroom-friendly websites for comic strips and userfriendly applications for teachers to make comic strips as their teaching media. However, there are also comic strips available online, with or without a paid subscription. Some websites provide comic strips to be read online, and teachers can use them in their classes, i.e., https://comics.azcentral.com/slideshow?comic $=g a, ~ h t t p s: / /$ loadingartist.com $/ \mathrm{comic} /$, and https://www.webtoons.com/en/.

Research from Cabrera et al. (2018), Chirkova et al. (2019), Da Silva et al. (2017), Kulıçkaya \& Krajka (2012), and Megawati \& Anugerahwati (2012) provide guidelines on how to use comic strips for language learning. Concerning the learning goals targeted, the teacher can incorporate the comic strips as parts of the teaching material, learning activities, or the assessment. When the comic strips are used as reading texts, the teacher can design the whilstactivity around the comic strips, such as discussions about the main idea of the comic strips or the new words in the comic strips. Likewise, when the comic strips are used as part of the assessment, the students' targeted performance can be designed around the comic strips: to make it a role-play, reading aloud, or reading comprehension. Another option to use the comic strips in language classrooms is to let the students make the comic strips themselves. 
The making of comic strips can be incorporated into the learning activities or the assessment, or both. In this case, one of the first steps that the teacher should do before advancing to comic strip making is to learn to make the comic strips, either manually or digitally and then teach the students how to do it. Thus, after setting the learning goals, the teacher can design the lesson plan that incorporates the making of comic strips: the teacher can think about the strategy to achieve the learning goals with comic strips, the teacher can make worksheets with comic strips, arrange activities to make comic strips, and how to teach the students to make their comic strips. Because the comic strips can be about anything, the teacher can incorporate the making of comic strips into any topic of language learning.

\section{METHOD}

Adopting George's (2008) library research, the present study answered the research questions through the results of previous studies and experts' opinions. Furthermore, this study adopted the adjustment of George's model (2008) into a qualitative design as done by Ariantini, Suwastini, Adnyani, Dantes, \& Jayantini (2021). Figure 1 displays the present study's steps of the library research as modeled on Ariantini et al.'s (2021) adaptation of George's (2008) library research.

The initial research procedure was selecting the topic, namely using comic strips in language teaching. It was followed by two research questions proposed regarding the benefits and challenges of using comic strips in language teaching. Systematic browsing and skimming were conducted to collect articles, books, and more sources related to the topic. The fourth step was determining the references and databases of the sources, namely Semantic Scholar, ERIC, Taylor and Francis Online, and SINTA, using Google Scholar as the searching tool. Considering the myriad of available sources, they were retrieved under the following criteria. First, the selected articles must be published in reputable international journals, accredited national journals, and other related sources deemed trustworthy to answer the present study's research questions. Second, to provide a more recent view, the articles must be published between 2011-2020. Third, specific keywords as listed in the figure were drawn to optimize the search result. This process resulted in twenty-five articles discussing the use of comic strips in teaching, including the benefits and challenges. Seven out of twenty-five articles were from journals indexed by SCOPUS, five were from journals indexed by SINTA, four were from international proceedings, and nine were from other sources. 


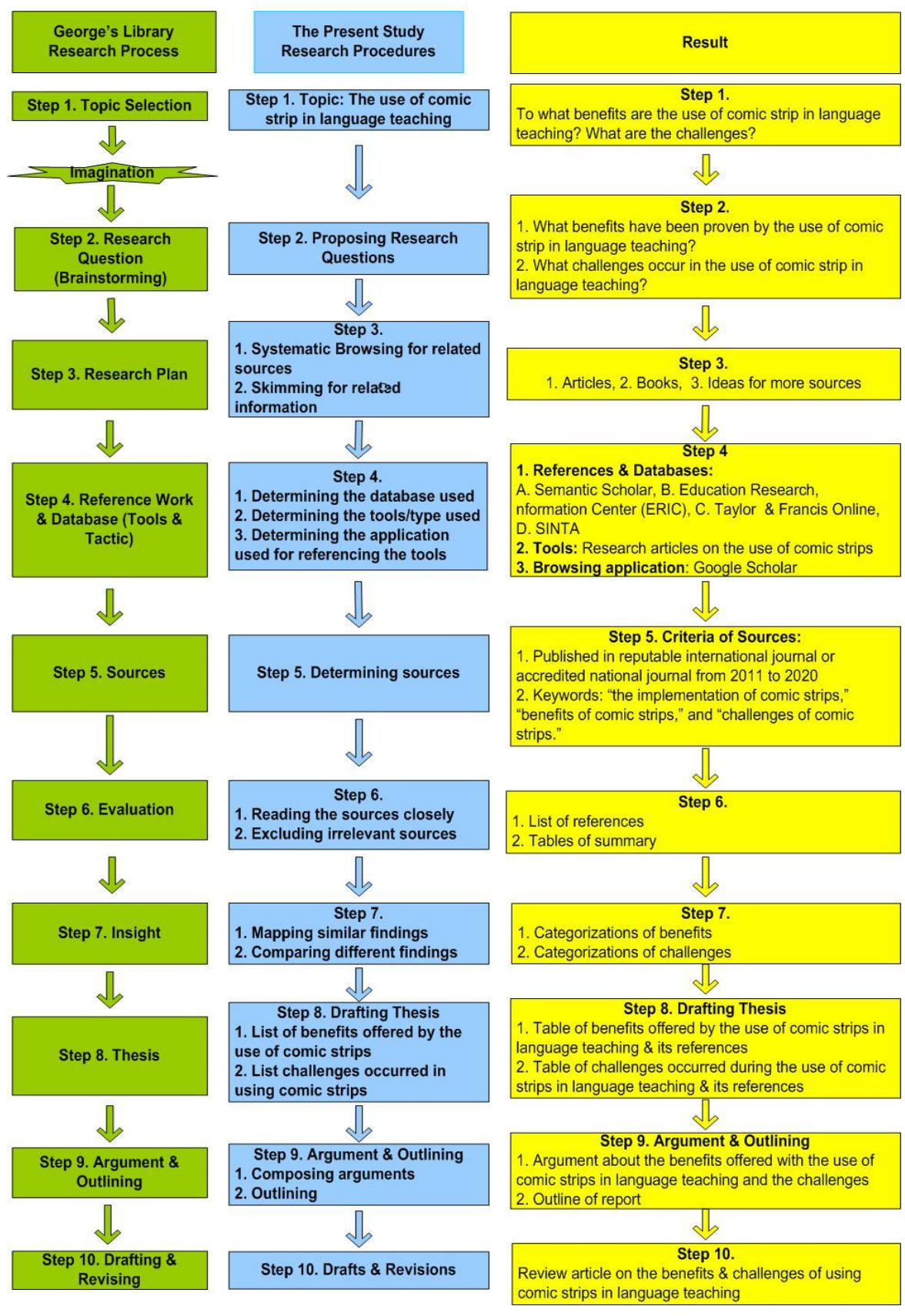

Figure 1. Research Procedure adapted from George (2008)

After the sources were collected, close reading started the data collection of recent findings on the use of comic strips in language teaching. The results were recorded in a table that summarises the sources, including the arguments, methods, findings, and recommendations made by previous studies. Further detailed information was added regarding the benefits and challenges of using comic strips in language teaching. Specifically, this literature review discussed the benefits of using comic strips in vocabulary, grammar, reading skills, and writing skills. Meanwhile, challenges in general, challenges in written skills, and challenges in speaking skills were also elaborated. To analyze the data that has been collected, a synthesis was made by comparing the similarities and differences. The synthesis 
Wijaya, E. A., Suwastini, N. K. A., Adnyani N. L. P. S., Adnyani, K. E. K., Comic Strips...

was used to build the thesis of the present studies on the use of comic strips in language teaching. The thesis was then developed into a review article discussing the benefits and challenges of using comic strips in language teaching.

\section{FINDINGS AND DISCUSSION}

\section{Benefits of Using Comic Strips for Language Teaching}

As one of the suitable teaching media in language teaching, comic strips for sure have their benefits. The benefits could be seen in using comic strips to improve language components and skills, such as vocabulary, grammar, reading skills, and writing skills.

\section{1) Comic Strips for Improving Vocabulary}

As one of the basics in language learning, vocabulary is essential. Budiman et al. (2018) and Cabrera et al. (2018) argue that vocabulary is one of the critical components that the students need to master in language learning. It is because vocabulary is the bridge to use and understand the language and the skills such as reading, writing, speaking, and listening. Thus, the teacher should create a learning situation that encourages the students to learn some new words. In this case, comic strips are beneficial for vocabulary learning (Cabrera et al., 2018; Cimermanová, 2015).

Chaikovska (2018) adds that comic-based activities reinforce traditional grammar and vocabulary tasks. Furthermore, Megawati (2012) states that comic strips are suitable for assisting the students to understand vocabulary. The pictures and the dialogues cooperate toward each other as the representation of the character's expression. Therefore, it could be said that the use of comic strips gives benefit in vocabulary learning. The benefits are 1) it helps to promote and facilitate vocabulary teaching, 2) it helps to improve vocabulary, and 3) it makes the learning process becomes fun and meaningful. Hereafter, the explanation could be seen as follows.

The first benefit is that it could be used to promote and facilitate vocabulary teaching. Chaikovska (2018), Hamidah et al. (2015), and Sharma (2020) argue that comic strips could be used to promote vocabulary. It could be seen in filling in the blank for the dialogues in the comic strips and creating sentences for the dialogues that required the students' vocabulary knowledge. Poai (2018) adds that pictures in comic strips facilitate vocabulary teaching. The use of comic strips containing pictures and simple words matched with the motion makes the students more interested in improving their vocabulary (Poai, 2018). Therefore, comic strips help the students learn vocabulary indirectly through the combination of pictures and words 
used in the comic strips themselves. Furthermore, it helps the students to memorize and recall words.

The second benefit is that it could be used to improve vocabulary. Budiman et al. (2018), Sarma (2016), and Sharma (2020) argue that comic strips help the students improve their vocabulary through the relation between the pictures and the caption in the comics that help them understand new words. Chaikovska (2018) also states that that the students could also learn synonyms and antonyms to expand their vocabulary through comic strips, adding new words into their repertoire when the students read comic strips and familiarize the use of the new words when the teacher required the students to create their comic strips. For Budiman et al. (2018), Humola \& Talib (2016), and Suwastomo (2016), reading comic strips helps the students to understand the text as well as improve their vocabulary. It is because there will be some new vocabulary provided in the comic strips.

The third benefit is that it makes the learning process becomes fun and meaningful. The use of comic strips makes the learning process fun (Cabrera et al., 2018; Chaikovska, 2018). The students could describe the pictures in the comic strips by using adjectives. Simultaneously, the students will remember the adjective because it is combined with the visualization to lead to vocabulary improvement. Thus, the learning process will become more fun and meaningful. Chaikovska (2018), Hamidah et al. (2015), and Sharma (2020) argue that the use of comic strips could promote higher-level thinking skills like analyzing skills through the process of comparing the panels. It is proven by Cabrera et al. (2018) and Kohnke (2018), who found that comic strips positively impacted vocabulary learning and effectively motivated the students to learn vocabulary in pleasant techniques. The use of comic strips allows the students to exercise creative control and show high enjoyment while interacting with comic strips.

\section{2) Comic Strips for Improving Grammar}

Chirkova et al. (2019) state that teaching grammar could be challenging because each language's grammar is arranged in its own way. In other words, each language has its grammatical categories and system. However, it could be overcome by using various methods, such as the use of comic strips as pedagogical cues. In this case, pedagogical cues related to the use of signs, different colors and fonts, and text boxes. It is assumed that comic strips as part of pedagogical cues create the cognitive learning process and an exciting learning process. The example of pedagogical cues could be seen in the form of comic strips. Thus, the use of comic strips also beneficial for grammar learning. Cimermanová (2015) argues that reading 
comic strips can positively affect the students' grammar. Chirkova et al. (2019) believe that comic strips to teach grammar is a famous mixed pedagogical cue and useful to increase the students' motivation, knowledge, skills, and abilities.

The first benefit is that it could promote exposure to the grammatical rules of the target language. Kiliçkaya \& Krajka (2012) and Sharma (2020) state that comic strips could be used as a reliable media for introducing grammar forms or functions by filling in the blank for the comic strips' dialogues and creating sentences for the dialogues. It also provides authentic material to illustrate how grammar is used in conversations. Thus, it could ease the students to understand the grammatical concepts of the target language. The use of comic strips can be focused on specific grammatical points by providing short and manageable contexts that the students need to write about (Rakhmawati, 2018).

The second benefit is that it could be used as a grammar exercise. Chirkova et al. (2019) state that comics could become a basis for grammar exercises through activities like filling in the speech bubbles, restoring a dialogue, or restoring the storyline. The same opinion comes from Poai (2018), in which the use of comic strips could be used to introduce and practice new grammatical points. Moreover, Chaikovska (2018) and Sarma (2016) add that the students could practice different verb tenses like changing present tense to past or future to write different forms of actions and transfer the comics' dialogue into indirect speech. Thus, comic strips as one of the pedagogical visualized cues help the students comprehend the material more straightforward, faster, and more effectively. Rochmawati (2019) states that the teacher could choose comic strips that show grammar points in a familiar medium for the students. Therefore, the students could read the comic strips, understand the use of grammar in context, and create their comic strips.

The third benefit is that it motivates the students to learn grammar in pleasant techniques. The use of comic strips also increased the students' motivation in language learning, especially in grammar, making the learning process more creative and promoting the development of the students' creative abilities (Al Faruq \& Nurhalimah, 2019; Chaikovska, 2018; Chirkova et al., 2019). Cabrera et al. (2018) and Kohnke (2018) found that the making of comic strips motivates the students to learn grammar in pleasant activities. For Al Faruq \& Nurhalimah (2019), comic strips can be pleasant media to learn grammar because the verbs used are illustrated in pictures as visual examples, which ease the students to understand the meaning. Therefore, the students could recognize the structures or grammar of a language through the dialogues presented in the comic strips. Furthermore, Rakhmawati (2018) insists that English comics could encourage the students to focus more on grammatical structure and 
make the teaching and learning process more exciting. Chirkova et al. (2019) found that pedagogical cues in grammar learning could reduce 10\% time in memorizing grammar structures.

\section{3) Comic Strips for Improving Reading Skill}

According to Cimermanová (2015), readers in today's era tend to find information on the internet rather than read and scan the whole text to find the information. In this case, it caused many students lack of reading skills. To overcome this problem, the teacher could use visualization to help the students to improve their reading skills. Cimermanová (2015) found that visualization, as in comic strips, helps the students understand the text's meaning easier by using metacognitive strategies. Besides, Chaikovska (2018) states that comic strips, mainly in pre-reading and reading tasks, make the students perform better than the students without comic strips. In other words, the use of comic strips could be beneficial for promoting and improving reading skills, motivating the students in the reading process, and making the learning process more effective.

The first benefit is that it could be used to promote and improve reading skills. Mahir et al. (2016) state that newspaper comic strips could promote students' reading skills. Similarly, Budiman et al. (2018), Cimermanová (2015), Manik (2019), and Poai (2018) argue that comic strips could help the students to improve their reading skills by improving their understanding of what they have read through the use of pictures and matched words with the pictures. Thus, the pictures act as assistance to make the text more comprehensible than mere texts without pictures. Moreover, Cabrera et al. (2018), Cimermanová (2015), and Mahir et al. (2016) maintain that comic strips could be used to improve students' reading skills, mainly focusing on lexical guessing using context. It improves the students' reading skills by helping the students to understand the text accompanied by visuals.

The second benefit of comic strips for reading skills is that they could motivate the students in the reading process. Cimermanová (2015) and Humola \& Talib (2016) argue that comic strips could motivate the students by developing reading strategies and easing the students to read the context of the text with the support of visualization. It is also stated that the use of visualization in comic strips could lead to readers' positive feelings and higher motivation. Manik (2019) states that the use of comic strips develops the students' interest in reading. Moreover, Cimermanová (2015) insists that comic strips can raise the students' in reading foreign texts by using comic strips in the learning process. Comic strips can help students overcome their linguistic barriers in reading authentic material (Cimermanová, 2015). 
Besides, comic strips can motivate students with different readiness to perform better because the visual cues aid their comprehension.

The third benefit is that it helps the students to learn reading skills more effectively. Rengur \& Sugirin (2019) state that comic strips could be used to teach reading, which can be more effective than conventional media. Specifically, the use of pictures in the comic strips supports the words or grammar used in the dialogues, making the text more comprehensible. The learners have to understand grammar in order to make them could understand the text. Therefore, the students' reading understanding and competence could be improved through comic strips. Cimermanová (2015) adds that comic strips make the learning process more effective by helping the students visualize or rely on the pictures to support them in reading and understanding foreign texts. It is also stated that the use of comic strips leads to the development of visual literacy. For Merc (2013), comic strips can help the students recall the text's content better in their reading comprehension because of the pictures accompanying the texts.

Comic strips could help the students in the process of reading. Budiman et al. (2018), Poai (2018), and Suwastomo (2016) state that comic strips could attract both the students who like to read and students who do not like to read because comic strips are usually funny and appealing, other than being short and practical. Megawati \& Anugerahwati (2012) add that the stories in the comic strips can act as language exposure that influences the students' way of thinking in reading, especially in understanding specific information. Thus, the visual representation in comic strips provides the students the meaning of the text and an exciting reading strategy (Chaikovska, 2018). Therefore, the teachers have to adjust the use of comic strips with the learning objectives and the student's proficiency to maximize comic strips and their function in language learning (Mahir et al., 2016).

\section{4) Comic Strips for Improving Writing Skill}

Besides beneficial for vocabulary, grammar, and reading skills, comic strips also are beneficial for writing skills. It is because vocabulary, grammar, and reading skills are connected with writing skills. According to Chaikovska (2018), comic strips are a potential teaching medium for teaching the students because the learning process engages with visual aids such as pictures, photographs, maps, cartoons, and video films. Suwastomo (2016) states that most students who learned with comic strips as the teaching media significantly improved content, organization, structure, and mechanics. Moreover, Chaikovska (2018) argues that the students could improve their writing skills when they required them to write an essay as the storyline before creating their comic strips. 
The first benefit is that it helps the students with writing difficulties. Budiman et al. (2018) and Chaikovska (2018) argue that that comic strips could help the students who lack writing to start their ideas and follow the sequence of ideas in line with the comic strips. Hamidah et al. (2015) conclude that comic strips could help the students generate ideas in the pre-writing, which becomes one of the biggest problems students face in writing skills. In this case, it could help the students to stimulate their imagination. The students could draw a picture to develop their ideas before starting to write the story. Yunus et al. (2011) add that comic strips could motivate students with low writing skills. Furthermore, comic strips are easy to apply, and it was helpful to help the students to develop and organize ideas in writing (Thresia, 2016). The use of comic strips also contributed to mechanics, especially spelling and punctuation (Megawati \& Anugerahwati, 2012).

The second benefit is that it could be used to promote and improve writing skills. Chaikovska (2018) found that the students who learned with comic strips performed better than those who learned with conventional methods. The students' tasks are accompanied by visuals that ease the students to understand the context. It also helps the students remember the grammar structure commonly used in the dialogue of the comic strips. Moreover, Cimermanová (2015) and Thresia (2016) have proven that the use of comic strips improved students' English writing ability and quality, especially the students' grammar, punctuation, and spelling as in writing story. Humola \& Talib (2016) prove that comic strips could enhance students' writing skills by improving the students' knowledge and ability to use simple past, conjunction, and possessive pronouns. Mahir et al. (2016) state that newspaper comic strips could be used to promote students' writing skills because comics lead to a fun and laid-back learning environment that helps the students understand something explained by the teacher easier.

The third benefit is that it could be a medium for interestingly practicing writing skills. According to Megawati \& Anugerahwati (2012), Sharma (2020), and Thresia (2016), the use of comic strips can motivate the students in practicing their writing skills because the combination of pictures and short texts keep the students interested. They also argue that making comic strips could improve the students' intellectual skills and give them the opportunity to show their creativity. In this case, the teacher could use comic strips to let the students practice their writing skills and improve their writing micro-skills. The students could focus on the comic strips' content, which is very interesting and will lead to their creative ideas in writing. Kılıçkaya \& Krajka (2012), for example, applied MakeBeliefsComix, an online comic strip creation site, to help improving writing class and provide fun writing skills 
Wijaya, E. A., Suwastini, N. K. A., Adnyani N. L. P. S., Adnyani, K. E. K., Comic Strips...

practices. It was found that $96 \%$ of the participants agree toward how comic strip gives enjoyment in creating the comic to support writing.

\section{Challenges in Using Comic Strips for Language Teaching}

Besides the benefits, comic strips also have their challenges in language teaching. Thus, it is essential to know the challenges of using comic strips in language teaching to maximize the use of comic strips in the learning process, such as the perception that comic strips are entertainment, limited information on how to use comic strips in language learning, lack of ideas on the part of the students, inappropriateness of content, and imbalanced language exercises for the students.

The first challenge in using comic strips to teach grammar could be found in how some people do not consider comic strips as a relevant strategy in language learning and minimum information about the use of comic strips in language learning. Fischer (2012) identifies resistance toward the use of comic strips as learning media on the ground that comic strips belong to entertainment. Thus they are not suitable for academic uses in language classrooms. However, Fischer (2012) is adamant that comic strips' use is not only for entertainment but also for improve the students' critical thinking. Comic strips could engage the students in the learning process that lead to their critical thinking. In this case, the students will try to engage in the learning process and understand the event occurring in each comic strip panel.

The second challenge is its unfamiliarity among language teachers. Chaikovska (2018), Kiliçkaya \& Krajka (2012), and Sarma (2016) notice that the use of comic strips in language learning is very limitedly documented; thus, many teachers are not aware of its benefits. Budiman et al. (2018) further elaborate that comic strips in language classrooms can be very varied. Thus, the teachers have to design the use of comic strips creatively to suit the learning objectives. The wide range of options for using comic strips in language learning is both a challenge and an opportunity. It is a challenge because the many options lead to confusion about which teaching procedure is the standard procedure for implementing comic strips in language classrooms. However, it is precisely here where the opportunity lies: teachers have the liberties to create their own procedures in implementing comic strips in their language classroom. Furthermore, teachers can also adjust the use of comic strips to their existing teaching procedures.

In the implementation of comic strips or improving students' writing skills, students are often found to be lacking ideas to write about. Chaikovska (2018) observes that students may find it challenging to decide what to write about. Moreover, when they have the idea, they were found to stumble on how to follow up the idea into a complete sequence that makes up 
a good story. Thus, according to Mahir et al. (2016), the teachers can carefully choose the suitable topic with the student's level of proficiency. It can pose a further complication for the teacher if the students happen to have different level of proficiency, interest, or readiness. If that happens, the teacher should be flexible with the topics to meet the students' different interests. The teacher should also adopt a certain degree of differentiated instruction to facilitate students with different proficiency levels and readiness, so the most competent students are kept challenged while the low-achieving students are not left behind (Ersani et al., 2021; Suwastini et al., 2021).

Chaikovska (2018), Rakhmawati (2018), and Rokhayani \& Utari (2014) recognize the challenge with the appropriateness of the comic strips' content with the students' age. Rakhmawati (2018) is most concerned with how comic strips sometimes contain pictures that are not appropriate for children. Indeed, some comic strips exaggerate body image that accentuates certain body parts that are not supposed to be revealed. The topic of the comic strips may also be age-inappropriate. Teachers should pay attention to racial slurs and discriminatory attitudes toward particular groups of people, including minorities and people with disabilities and special needs. Wordings in comic strips can also be casual and, at times, include rude words. Thus, Chaikovska (2018) insists that the teacher carefully chooses the comic strips and pays attention to the language and topics.

Rokhayani \& Utari (2014) are concerned with another challenge in using comic strips in language classrooms. They warn that comic strips may not be as effective for improving students' speaking and listening skills as they are for improving students' reading and writing skills. They elaborate that comic strips do not have audio features that may have benefited students' exposure to the target language's native speech. In this case, the students only rely on the teachers' pronunciation of the dialogues' sentences. Such situation may endanger students' language development when the teacher does not read the comic strips with proper pronunciation and accents. Thus, the teacher needs to ensure that all words are correctly pronounced, and the characters' speeches are spoken with the right accents and intonations. To cover for the students' speaking practice, Rokhayani \& Utari (2014) suggest implementing comic strips in language learning to include the students to read aloud their comics, either directly in front of the class or in a recording. They argue that integrating the activities will make the students have long-term memory and understanding of the dialogue and the concept of the grammar. Similarly, Kohnke (2018) insists that the teacher could ask the students to act out the comic strips with correct intonation and rhythm. Moreover, the teacher could give the students a chance to describe the comic strips given by the teacher. 
Wijaya, E. A., Suwastini, N. K. A., Adnyani N. L. P. S., Adnyani, K. E. K., Comic Strips...

\section{E. CONCLUSION}

As one of the suitable teaching media in today's era, comic strips could be used in language teaching. Several studies proved the effectiveness of using comic strips in language teaching with its benefits and challenges. All of those studies agreed that the use of comic strips in language teaching is beneficial. Using comic strips, the learners could express their ideas in the form of images and learn a language. It also improved the students' language components mastery, such as vocabulary and grammar and their reading and writing skills. In this case, comic strips to teach vocabulary and grammar could be seen in the process of introducing modals and pronouns and changing direct speech into indirect speech in the speech balloon. Comic strips also support the words or grammar used in the dialogues, making the text more comprehensible for the students as in learning written skills.

However, there are also several challenges in implementing comic strips in language classrooms, so the teachers need to be creative and critical. Teachers should balance the use of comic strips so that it serves academic purposes in addition to being entertaining and casual reading materials. Teachers also need to be creative in using comic strips because there are many possible procedures in its implementation. Teachers also need to suit the topic of the assignment with the students' proficiency, readiness, and interests so they are kept interested, motivated and benefited from the use of comic strips. Besides, variations should also be made to balanced the reading and writing exposure that the comic strips offer with requirements that allow the students to practice their listening and speaking skills. Furthermore, it is essential to pay attention to the choices of the topics and the content to avoid exposing the students to age-inappropriate, abusive, or politically incorrect content.

\section{REFERENCES}

Al Faruq, H. A., \& Nurhalimah. (2019). Comic strips in teaching simple past tense for EFL learners. ELLITE: Journal of English Language, Literature, and Teaching, 3(2), 53-56. https://doi.org/http://dx.doi.org/10.32528/ellite.v3i2.1912

Ariantini, K. P., Suwastini, N. K. A., Adnyani, N. L. P. S., Dantes, G. R., \& Jayantini, I. G. A. S. R. (2021). Integrating social media into English language learning: How and to what benefits according to recent studies. NOBEL: Journal of Literature and Language Teaching, 12(1), 91-111. https://doi.org/https://doi.org/10.15642/NOBEL.2021.12.1.91-111

Budiman, P. G., Sada, C., \& Wardah. (2018). Improving students vocabulary by using comic strips in teaching narrative text. Jurnal Pendidikan Dan Pembelajaran Khatulistiwa, 7(9), 1-8. Retrieved from https://jurnal.untan.ac.id/index.php/jpdpb/article/download/28279/75676578327

Cabrera, P., Castillo, L., González, P., Quiñónez, A., \& Ochoa, C. (2018). The impact of using Pixton for teaching grammar and vocabulary in the EFL Ecuadorian context. Teaching English with Technology, 18(1), 53-76. Retrieved from 
http://cejsh.icm.edu.pl/cejsh/element/bwmeta1.element.desklight-65acf8b1-db70-4a7a9a8c-88afc73583a3/c/ARTICLE4.pdf

Chaikovska, O. (2018). Benefits of teaching ESL through comic strips. Web of Scholar, 4(1), 8 $11 . \quad$ Retrieved from https://www.academia.edu/37665857/BENEFITS_OF_TEACHING_ESL_THROU GH_COMIC_STRIPS

Chirkova, E., Chernovets, E., \& Zorina, E. (2019). Visualization method of educational information of the English language grammar communicative teaching in a nonlinguistic university. Proceedings of EDULEARN19, 609-613. https://doi.org/http://dx.doi.org/10.21125/edulearn.2019.0214

Cimermanová, I. (2015). Using comics with novice EFL readers to develop reading literacy. Procedia - Social and Behavioral Sciences, 174(2015), 2452-2459. https://doi.org/https://doi.org/10.1016/j.sbspro.2015.01.916

Da Silva, A. B., Santos, G. T. Dos, \& Bispo, A. C. K. de A. (2017). The comics as teaching strategy in learning of students in an undergraduate management program. Human and Social Management, 18(1), 40-65. https://doi.org/https://doi.org/10.1590/167869712017/administracao.v18n1p40-65

Ersani, N. P. D., Suwastini, N. K. A., Padmadewi, N. N., \& Artini, L. P. (2021). Schemes of scaffolding in online education. Retorika: Jurnal Ilmu Babasa, 7(1), 10-18. https://doi.org/https://doi.org/10.22225/jr.7.1.2941.10-18

Fischer, J. (2012). Using innovative teaching techniques and technological tools to teach grammar points in Spanish and how they increase student engagement. International Journal for Cross-Disciplinary Subjects in Education (IJCDSE), 2(2), 1025-1028. Retrieved from https://infonomics-society.org/wp-content/uploads/ijcdse/publishedpapers/special-issue-volume-2-2012/Using-Innovative-Teaching-Techniques-andTechnological-Tools-to-Teach-Grammar-Points-in-Spanish-and-How-They-IncreaseStudent-Engagement.pdf

George, M. W. (2008). The elements of library research: What every student needs to know. Princeton: Princeton University Press.

Gilakjani, A. P., Ismail, H. N., \& Ahmadi, S. M. (2011). The effect of multimodal learning models on language teaching and learning. Theory and Practice in Language Studies, 1(10), 1321-1327. https://doi.org/doi:10.4304/tpls.1.10.1321-1327

Hamidah, N., Usman, S., \& Muhsin. (2015). Improving writing skill of the eight graders through comic strip. E-Journal of English Language Teaching (ELTS), 3(2), 1-11. Retrieved from http://jurnal.untad.ac.id/jurnal/index.php/ELTS/article/download/4420/3297

Humola, Y., \& Talib, R. (2016). Enhancing the students' writing ability by using comic strips: An action research conducted at the tenth grade of SMA Negeri 1 Tapa. ICTTE, 1(1).

Hutapea, J. V., \& Suwastini, N. K. A. (2019). Using short films for teaching English while building characters. Lingua Scientia, 26(1), 33-37. https://doi.org/10.23887/1s.v26i1.18846 
Kilıçkaya, F., \& Krajka, J. (2012). Can the use of web-based comic strip creation tool facilitate EFL learners' grammar and sentence writing? British Journal of Educational Technology, 43(6), 161-165. https://doi.org/https://doi.org/10.1111/j.1467-8535.2012.01298.x

Kohnke, L. (2018). Using comic strips to stimulate student creativity in language learning. TESOL Journal, 10(2), 419-423. Retrieved from https://doi.org/10.1002/tesj.419

Listiani, N. K. M., Suwastini, N. K. A., Dantes, G. R., Adnyani, N. L. P. S., \& Jayantini, I. G. A. S. R. (2021). YouTube as digital learning resources for teaching bilingual young learners. Proceedings of the 2nd International Conference on Technology and Educational Science (ICTES 2020), 540(ICTES 2020), 156-162. https://doi.org/https://dx.doi.org/10.2991/assehr.k.210407.230

Mahir, N. A., Ali, R. M., \& Amin, K. M. (2016). Using newspaper comics strips to improve reading and writing among MUET Band $1 \& 2$ year 1 students of Faculty of Quran and Sunnah Studies, University Sains Islam Malaysia (USIM). Journal of Global Business and Social Entrepreneurship (GBSE), 2(3), 57-62. Retrieved from http://gbse.com.my/isijulai16/GBSE 2(3), 57-62 (July 2016).pdf

Manik, R. M. S. (2019). The effectiveness of comic strip as media to improve the students' reading comprehension on narrative text of MTs Ar-Rahman Langkat. The 2nd Annual International Conference on Language and Literature (AICLL 2019), 933-947. Retrieved from https://knepublishing.com/index.php/KnE-Social/article/view/4918/9844

Megawati, F., \& Anugerahwati, M. (2012). Comic strips: A Study on the teaching of writing narrative texts to Indonesian EFL students. TEFLIN Journal, 23(2), 183-205. https://doi.org/http://dx.doi.org/10.15639/teflinjournal.v23i2/183-205

Merc, A. (2013). The effect of comic strips on EFL reading comprehension. International Journal of New Trends in Education and Their Implications (IJONTE), 4(1), 54-64. Retrieved from http://www.ijonte.org/FileUpload/ks63207/File/05.merc.pdf

Poai, S. T. (2018). Teaching English vocabulary using comic strips. Sintumu Maroso Journal of English Teaching (JET), 4(1), 51-58. Retrieved from https://ojs.unsimar.ac.id/index.php/sintuwumarosoJET/article/download/153/138

Puspawati, N. W. N., Suwastini, N. K. A., Hutapea, J. V., Dantes, G. R., \& Adnyani, N. L. P. S. (2021). Consumption and Production of Short Film: Toward the Conceptualization of Multimodal Language Learning for Developing 6Cs Skills in the Digital Age. Journal of Physics: Conference Series, 1810(1). https://doi.org/10.1088/1742-6596/1810/1/012054

Rakhmawati, D. (2018). The effectiveness of English comic in teaching grammar (present and past tense). SMART: Journal of English Language Teaching and Applied Linguistics, 4(1), 52-60.

Rengur, Z., \& Sugirin, S. (2019). The effectiveness of using comic Strips to increase students' reading comprehension for the eighth grade students of SMPN 1 Pundong. Proceedings of the 6th International Conference on Educational Research and Innovation (ICERI 2018), 239-243. Retrieved from https://dx.doi.org/10.2991/iceri-18.2019.49

Rochmawati, D. (2019). Innovative techniques of teaching English grammar at secondary schools. Journal of English Teaching Adi Buana, 4(2), 152-159. Retrieved from 
http://jurnal.unipasby.ac.id/index.php/jet/article/download/2077/1864/

Rokhayani, A., \& Utari, A. R. P. (2014). The use of comic strips as an English teaching media for junior high school students. LANGUAGE CIRCLE: Journal of Language and Literature, 7(2), 143-149. Retrieved from https://journal.unnes.ac.id/nju/index.php/LC/article/view/3018

Sarma, L. S. (2016). Teaching English through comics. Indian Journal of Applied Research, 6(6), 283-284. Retrieved from https://www.worldwidejournals.com/indian-journal-ofapplied-research-(IJAR)/fileview/June_2016_1464768478_90.pdf

Sharma, R. (2020). Comics: A tool of teaching language through literature. International Journal of Creative Research Thoughts (IJCRT), 8(4), 3200-3204. Retrieved from https://ijcrt.org/papers/IJCRT2004452.pdf

Suwastini, N. K. A., Dantes, G. R., Jayanta, I. N. L., \& Suprihatin, C. T. (2020). Developing Storyline for Role-Playing Games Based on Balinese Folklore for Preserving Local Wisdom and Character Education. 394(Icirad 2019), 361-366. https://doi.org/10.2991/assehr.k.200115.059

Suwastini, N. K. A., Lasmawan, W., Artini, N. N., \& Mahayanti, N. W. S. (2020). Mixed messages about environmental awareness in Disney's 2016 Finding Dory. The Asian EFL Journal, 27(4.1), 73-93. Retrieved from https://www.asian-efl-journal.com/wpcontent/uploads/AEJ-Volume-27-Issue-4.1-October-2020.pdf

Suwastini, N. K. A., Rinawati, N. K. A., Jayantini, I. G. A. S. R., \& Dantes, G. R. (2021). Differentiated instruction across EFL classrooms: A conceptual review. TELL-US Journal, 7(1), 14-41. https://doi.org/http://dx.doi.org/10.22202/tus.2021.v7i1.4719

Suwastini, N. K. A., Utami, I. G. . L. P., \& Artini, N. N. (2020). Dory's paradoxical characterizations in Disney's animated feature film Finding Dory (2016). NOBEL: Journal of Literature and Language Teaching, 11(1), 27-37. https://doi.org/10.15642/nobel.2020.11.1.27-37

Suwastomo, B. (2016). Teaching using comic as a media to improve student's vocabulary mastery at tenth grade of SMAN 1 Muntok. Studia: Jurnal Hasil Penelitian Mahasiswa, 1(1), 1-22. Retrieved from https://jurnal.lp2msasbabel.ac.id/index.php/stu/article/view/483

Syafii, M. L. (2019). Implementing writing process approach with pictures to improve the ability of the eighth grades in writing recounts. ETERNAL (English, Teaching, Learning, and Research Journal), 5(2), 254-273. Retrieved from https://www.readcube.com/articles/10.24252\%2Feternal.v52.2019.a7

Thresia, F. (2016). The Effectiveness of CIRC Method and comic-strip media to English writing ability. Proceedings of the Ninth International Conference on Applied Linguistics (CONAPLIN 9), 77-80. https://doi.org/https://dx.doi.org/10.2991/conaplin16.2017.16

Utami, L. P. R. A., Suwastini, N. K. A., Dantes, G. R., Suprihatin, C. T., \& Adnyani, K. E. K. (2021). Virtual reality for supporting authentic learning in 21-st century learning. Jurnal Pendidikan Teknik Dan Kejuruan, 18(1), 132-141. Retrieved from 
Wijaya, E. A., Suwastini, N. K. A., Adnyani N. L. P. S., Adnyani, K. E. K., Comic Strips...

https://ejournal.undiksha.ac.id/index.php/JPTK/article/viewFile/32376/17649

Yunus, M. M., Salehi, H., Tarmizi, A., Idrus, S. F. S., \& Balaraman, S. S. (2011). Using digital comics in teaching ESL writing. Proceedings of the 2nd International Conference on Arts and Culture, 53-56. Retrieved from http://www.wseas.us/elibrary/conferences/2011/Montreux/COMICICBIO/COMICICBIO-07.pdf 